\title{
Oscillation of even-order neutral differential equations via comparison principles
}

\section{J. DŽURINA and B. BACULÍKOVÁ}

\section{ABSTRACT.}

In the paper we offer oscillation criteria for even-order neutral differential equations

$$
\left(r(t)\left[z^{(n-1)}(t)\right]^{\gamma}\right)^{\prime}+q(t) x^{\gamma}(\sigma(t))=0,
$$

where $z(t)=x(t)+p(t) x(\tau(t))$. Establishing a generalization of Philos and Staikos lemma, we introduce new comparison principles for reducing the examination of the properties of the higher order differential equation onto oscillation of the first order delay differential equations. The results obtained are easily verifiable.

\section{REFERENCES}

[1] Agarwal, R. P. and Grace, S. R., Oscillation theorems for certain neutral functional differential equations, Comput. Math. Appl., 38 (1999), 1-11

[2] Baculíková, B., Graef, J. and Džurina, J., On the oscillation of higher order delay differential equations, Nonlinear oscillations, 15 (2012), 13-24

[3] Baculíková, B., Properties of third order nonlinear functional differential equations with mixed arguments, Abstr. Appl. Anal., 2011, 1-15

[4] Baculíková, B. and Džurina, J., Oscillation of third-order functional differential equations, EJQTDE, 43 (2010), $1-10$

[5] Baculíková, B. and Džurina, J., Oscillation theorems for second order neutral differential equations, Comput. Math. Appl., 61 (2011), 94-99

[6] Džurina, J., Comparison theorems for nonlinear ODE's, Math. Slovaca, 42 (1992), 299-315

[7] Džurina, J. and Stavroulakis, I. P., Oscillation criteria for second order delay differential equations, Appl. Math. Comput., 140 (2003) 445-453, Zbl 1043.34071

[8] Han, Z., Li, T., Sun, S. and Chen, W., Oscillation criteria for second-order nonlinear neutral delay differential equations, Adv. Difference. Equ., (2010) 1-23

[9] Kiguradze, I. T. and Chaturia, T. A., Asymptotic Properties of Solutions of Nonatunomous Ordinary Differential Equations, Kluwer Acad. Publ., Dordrecht 1993

[10] Ladde, G. S., Lakshmikantham, V. and Zhang, B. G., Oscillation Theory of Differential Equations with Deviating Arguments, Marcel Dekker, New York, 1987

[11] Li, T., Han, Z., Zhao, P. and Sun, S., Oscillation of even-order neutral delay differential equations, Adv. Difference. Equ.,(2010) 1-9

[12] Philos, Ch. G., Oscillation and asymptotic behavior of linear retarded differential equations of arbitrary order, Univ. Ioannina, Tech. Report No. 57, 1981

[13] Philos, Ch. G., On the existence of nonoscillatory solutions tending to zero at $\infty$ for differential equations with positive delay, J. Austral. Math. Soc., 36 (1984), 176-186

[14] Zhang, Ch., Li, T., Sun, B. and Thandapani, E., On the Oscillation of Higher-Order Half-Linear Delay Differential Equations, Appl. Math. Letters, 24 (2011), 1618-1621

[15] Xing, G., Li, T. and Zhang, CH., Oscillation of higher-order quasi-linear neutral differential equations, Adv Diff. Equ., (2011)

Received: 14.06.2013; In revised form: 03.10.2013; Accepted: 20.10.2014

2010 Mathematics Subject Classification. 34K11, 34C10.

Key words and phrases. Even-order neutral differential equations, comparison theorem, oscillation.

Corresponding author: J. Džurina; jozef.dzurina@tuke.sk 
Department of Mathematics

TECHNICAL UNIVERSITY OF KOŠICE

LetNá 9, 04200 KoŠICE, SLOVAKIA

E-mail address: blanka.baculikova@tuke.sk

E-mail address: jozef.dzurina@tuke.sk 